\title{
A surprise for you and me?
}

Citation for published version (APA):

Schumacher, A. (2019). A surprise for you and me? The effect of surprise appeals and choices for close others on consumption experience. [Doctoral Thesis, Maastricht University]. Off Page Amsterdam. https://doi.org/10.26481/dis.20190620ans

Document status and date:

Published: 01/01/2019

DOI:

10.26481/dis.20190620ans

Document Version:

Publisher's PDF, also known as Version of record

\section{Please check the document version of this publication:}

- A submitted manuscript is the version of the article upon submission and before peer-review. There can be important differences between the submitted version and the official published version of record.

People interested in the research are advised to contact the author for the final version of the publication, or visit the DOI to the publisher's website.

- The final author version and the galley proof are versions of the publication after peer review.

- The final published version features the final layout of the paper including the volume, issue and page numbers.

Link to publication

\footnotetext{
General rights rights.

- You may freely distribute the URL identifying the publication in the public portal. please follow below link for the End User Agreement:

www.umlib.nl/taverne-license

Take down policy

If you believe that this document breaches copyright please contact us at:

repository@maastrichtuniversity.nl

providing details and we will investigate your claim.
}

Copyright and moral rights for the publications made accessible in the public portal are retained by the authors and/or other copyright owners and it is a condition of accessing publications that users recognise and abide by the legal requirements associated with these

- Users may download and print one copy of any publication from the public portal for the purpose of private study or research.

- You may not further distribute the material or use it for any profit-making activity or commercial gain

If the publication is distributed under the terms of Article $25 \mathrm{fa}$ of the Dutch Copyright Act, indicated by the "Taverne" license above, 


\section{SUMMARY}

This dissertation investigates how uncertainty appeals and close others influence hedonic consumption choices and experiences. Chapter 2 shows that uncertainty appeals in form of surprise labels encourage choice. Specifically, surprise labels trigger a heightened level of perceived uncertainty, which -if resolved - entails a rewarding experience of uncertainty resolution. It is this rewarding experience of uncertainty resolution that promotes consumers' expectation of an enjoyable consumption experience and thereby increases their quantity chosen for intended consumption.

Chapter 3 demonstrates that even though consumers expect to enjoy surprise-labeled products more than products without such label, they enjoy the actual consumption experience less, consume less from surprise-labeled products and display a reduced desire to continue consumption. This is because the heightened state of vigilance triggered by surprise labels distorts attention away from the focal consumption experience as consumers intuitively remain alert for new incoming cues that may reveal the actual "surprise" associated with the consumption experience. As a consequence of this heightened state of anticipation, consumers become less immersed in the focal consumption experience and thus, enjoy it less.

Finally, Chapter 4 investigates how choices for close others influence subsequent self-indulgence by the chooser. Our findings suggest that choosers with high power in the relationship with the choice target are more likely to self-indulge after making a healthy choice for a low-power close other. Conversely, choosers with low power in their relationship with the choice target are less likely to self-indulge after making a healthy other-oriented choice. 